\title{
The Increase of Surface Area of a Brazilian Palygorskite Clay Activated with Sulfuric Acid Solutions Using a Factorial Design
}

\author{
Oliveira, R. N. ${ }^{\mathrm{a} *}$, Acchar, W. ${ }^{\mathrm{b}}$, Soares, G. D. A. ${ }^{\mathrm{a}}$, Barreto, L. S. \\ ${ }^{\mathrm{a}}$ Metallurgical and Materials Engineering, Federal University of Rio de Janeiro - UFRJ, \\ P.O. box 68505, CEP 21941-972, Rio de Janeiro, RJ, Brazil \\ ${ }^{\mathrm{b}}$ Physics Department, Federal University of Rio Grande do Norte - UFRN, \\ CEP 59072-970 Lagoa Nova, RN, Brazil \\ 'Material Science and Engineering Program - P2CEM, Federal University of Sergipe - UFS, \\ CEP 49100-000, São Cristóvão, SE, Brazil
}

Received: June 26, 2012; Revised: January 17, 2013

\begin{abstract}
Palygorskite is fibrous clay in which the structural tetrahedral and octahedral layers are organized in a way that structural channels are formed, leading to high surface area. However, impurities inside the channels and aggregated ones considerably reduce the available area. In order to increase the surface area, an activation treatment can be considered useful. The goal of this work is the activation of palygorskite from Guadalupe, Piauí, via sulfuric acid treatment using a two-level factorial design. The influence of three parameters (solution molarity, temperature and time) on BET surface area was determined. Moreover, samples were characterized via X-ray diffraction (XRD) and fluorescence (XRF), Fourier-transform infrared spectroscopy (FTIR) and transmission electron microscopy (TEM). The largest surface area $\left(282 \mathrm{~m}^{2} / \mathrm{g}\right)$ without considerable changes in clay structure and morphology was found in a sample treated with $5 \mathrm{M} \mathrm{H}_{2} \mathrm{SO}_{4}$ at $70^{\circ} \mathrm{C}$ for $1 \mathrm{~h}$. The main parameters that favored the improvement of the surface area were the solution's molarity, temperature and their interaction.
\end{abstract}

Keywords: palygorskite, acid activation, sulfuric acid, factorial design

\section{Introduction}

According to the Comité International pour l'Étudedes Argiles (CIPEA), clays can be classified as lamellar or fibrous. Fibrous clays present high aspect ratio and structural channels. The main clay-minerals that compose this family are palygorskite and sepiolite ${ }^{1-3}$.

Palygorskite is a natural fibrous clay, whose structure is composed of layers of silicon tetrahedra placed between octahedral layers of magnesium, partially substituted by aluminum and/or iron ${ }^{4,5}$. The periodic inversion of the silica tetrahedra allows the formation of a fibrous morphology and it generates structural channels, which characterize these clays. In 1982, a palygorskite site was discovered in Guadalupe, Piauí, Brazil ${ }^{6,7}$. Some authors have studied palygorskite from Piauí and realized that aluminum and iron are present not only as substitution cations in the clay structure, but also as impurities ${ }^{7,8}$. Sodium and potassium are present as cations of network compensation.

The fibrous morphology justifies the variation in surface area from tens to hundreds of $\mathrm{m}^{2} / \mathrm{g}$. Since the clay has a natural origin, the channels can be full of impurities. Moreover, other materials like quartz and carbonates can be aggregated ${ }^{5,9-13}$.

Palygorskite has been used in health care for different goals: purification of domestic water ${ }^{4}$; in the formulation of intestinal adsorbents for toxic agents ${ }^{14}$; $\operatorname{cosmetics}^{15}$;

*e-mail: renataoliveira@poli.ufrj.br as a filler, improving mechanical strength, in polymer formulations to be used as wound dressings ${ }^{16}$; etc. The application of these clays in health care requires the removal of both the aggregated material and the channel's impurities. In particular, quartz can be problematic: according to the International Agency for Research on Cancer / IARC ${ }^{17}$, inhaled quartz can result in a carcinogenic effect. The aggregated quartz cannot be eliminated via a chemical route, since its composition is very similar to palygorskite's. So a physical route like sedimentation would be a viable choice for quartz removal.

The impurities inside the channels can be removed via acid activation, which increases the surface area. Increasing the surface area is particularly relevant in drug delivery systems: the larger the area, the greater the amount of drug adsorbed $^{10}$. The final area of treated clay is dependent on treatment time, temperature and solution concentration. In acid solution, the protons $\left(\mathrm{H}^{+}\right)$react with the octahedral cations such as $\mathrm{Al}, \mathrm{Fe}, \mathrm{Mg}$ and they are released to the solution. The acid cleans the structural channels but an undesirable leaching can also occur, depending on the activation's parameters ${ }^{18-21}$.

The goal of this work was to remove impurities aggregated to the clay and to activate the palygorskite by sulfuric acid treatment, using a factorial design method, in order to determine the influence of activation parameters. 


\section{Material and Methods}

A clay from Piaú, Brazil, was analyzed via X-ray diffraction - XRD (Shimadzu diffractometer XRD 6000, $\mathrm{Cu} \mathrm{K} \alpha$ radiation, from $5^{\circ}$ to $60^{\circ}, 30 \mathrm{kV} / 30 \mathrm{~mA}$ ) to determine which phases were present. As expected, the main aggregated components were quartz (JCPDS 05-0490) and dolomite (JCPDS 36-0426). To remove part of the quartz, an aqueous dispersion of palygorskite (1/10, clay/water) had been prepared, the clay sedimented and the supernatant was filtered, followed by drying in a $100{ }^{\circ} \mathrm{C}$ oven. After sedimentation, the most intense peak of quartz $\left(2 \theta=26.55^{\circ}\right)$ was considerably reduced and the clay - which we called non-treated (NT) - was then submitted to the acid treatments, which would also remove the dolomite.

For all tests, $1 \mathrm{~g}$ of NT palygorskite was immersed in sulfuric acid (Vetec) solutions at different temperatures and time intervals, according to a $2^{3}$ factorial design. The use of a factorial design is intended to evaluate the influence of each chosen variable (solution molarity, time and temperature) in activation; and the influence of the interactions of variables by selecting lower and upper levels of these variables, as shown in Table 1.

The experimental design, obtained using the Minitab $15^{\circledR}$ program, followed the order displayed in Table 2.

The quantification of chemical elements of selected samples was carried out by X-ray fluorescence - XRF (Rigaku RX3100). The microstructural characterization was performed using XRD and Fourier-transform infrared spectroscopy - FTIR (Perkin Elmer, from $4000 \mathrm{~cm}^{-1}$ to $550 \mathrm{~cm}^{-1}$ ). Some samples were also analyzed by transmission electron microscopy - TEM (JEOL FX 2000, $200 \mathrm{kV}$ ) in order to observe the clay morphology. For this, a small quantity of clay powder was dispersed in acetone and dropped on a copper grid coated with formvar film.

The response variable in this study was the BET surface area, measured in a Micromeritics equipment, model ASAP 2020, and the results were analyzed using the Minitab 15 program. The codified mathematical model for the $2^{3}$ factorial design is displayed in equation 1 , where $\mathrm{Y}$ is the response (surface area), $b_{0}$ is the global mean and the $b_{i}$, $b_{i j}$ and $b_{i j k}$ are regression coefficients. A 95\% confidence level and 8 degrees of freedom student t-test analyzed the significance of the variables and of the variables' interactions.

Table 1. Factorial design variables and levels, where $(-1)$ is the lower level; (0), the midpoint; and (+1), the upper one.

\begin{tabular}{lccc}
\hline \multicolumn{1}{c}{ Operating variable } & $(\mathbf{- 1})$ & $\mathbf{( 0 )}$ & $\mathbf{( + 1 )}$ \\
\hline $\mathrm{x}_{1}$ (molarity of the solution) $(\mathrm{mol} / \mathrm{L}, \mathrm{M})$ & 1 & 3 & 5 \\
$\mathrm{x}_{2}$ (time) $(\mathrm{h})$ & 1 & 3 & 5 \\
$\mathrm{x}_{3}$ (temperature) $\left({ }^{\circ} \mathrm{C}\right)$ & 25 & 47.5 & 70 \\
\hline
\end{tabular}

$Y=b_{0}+b_{1} x_{1}+b_{2} x_{2}+b_{3} x_{3}+$
$b_{12} x_{1} x_{2}+b_{13} x_{1} x_{3}+b_{23} x_{2} x_{3}+b_{123} x_{1} x_{2} x_{3}$

\section{Results and Discussion}

The XRF of the sedimented clay (NT sample) showed that the main elements of the sample are that of the claysilicate (23.4 wt. (\%) Si, 11.5 wt. (\%) Mg, 7.7 wt. (\%) Al) plus 3.5 wt. (\%) $\mathrm{Fe}, 0.9$ wt. (\%) $\mathrm{K}$ and 6.9 wt. (\%) Ca. Calcium is related to the aggregated dolomite. Magnesium belongs to palygorskite and also to dolomite, and iron can partially replace the magnesium in the palygorskite structure. The presence of potassium indicates cations compensation network. Other impurities, such as titanium, were not detected, but could be present as content lower than $1.00 \%$, which was below the detection threshold of this technique. The resulting surface area of this condition was equal to $84 \mathrm{~m}^{2} / \mathrm{g}$.

The XRD patterns of all acid-activated samples, following the data of Table 2, can be observed in Figure 1. Note the absence of dolomite peaks (at $2 \theta=31.04^{\circ}$ and at $2 \theta=41.28^{\circ}$ ) for all conditions, confirming the removal of dolomite by sulfuric acid solutions.

The intensity of the major peak related to quartz $\left(2 \theta=26.55^{\circ}\right)$ was almost constant, independent of treatment conditions. The XRD patterns showed that the palygorskite treated with $1 \mathrm{M} \mathrm{H}_{2} \mathrm{SO}_{4}$ (samples 1 to 4 ) and $3 \mathrm{M} \mathrm{H}_{2} \mathrm{SO}_{4}$ (sample 5) maintained its structure, since the major peaks of palygorskite (JCPDS 31-0783) remained without considerable changes. The treatment with solutions $5 \mathrm{M}$ $\mathrm{H}_{2} \mathrm{SO}_{4}$ was effective in palygorskite activation, but the most severe treatment (sample 9 , treated at $70{ }^{\circ} \mathrm{C}$ for 5 hours) leached the clay, as the peaks corresponding to palygorskite were almost absent. According to Frini-Srasra and Srasra ${ }^{20}$, the acid activation can decrease the clay crystallinity due to octahedral cations $(\mathrm{Mg}, \mathrm{Fe}$ and $\mathrm{Al})$ removal. However, this process begins slowly, since the channels are still closed. After that, $\mathrm{H}+$ can access the channels and the protons not only remove the impurities inside the channels, but they also begin leaching the octahedral cations.

Figure 2 shows the FTIR spectra of samples NT, 7 and 9, where the spectrum for sample 7 represents all other spectra. On sample NT and 7 the bands related to the major bindings between palygorskite's elements and between silica's elements were present.

The bands of the non-treated (NT) sample are marked $(*)$ and they refer to the binding vibration of aluminum-silicates, which are also found in all activated samples that are non leached, like sample 7. The bands were dislocated when compared to the results of Augsburger et al. ${ }^{11}$. The bands and the respective binding vibrations were: at $3614 \mathrm{~cm}^{-1}, \mathrm{OH}$ stretching mode of $\mathrm{M}_{2}-\mathrm{OH}$, where $\mathrm{M}$ is $\mathrm{Al}$ or $\mathrm{Fe}$; at $3543 \mathrm{~cm}^{-1}$, usually related to coordinated water; at $1650 \mathrm{~cm}^{-1}, \mathrm{HOH}$

Table 2. Factorial design order displays all samples produced.

\begin{tabular}{lccccccccc}
\hline \multicolumn{1}{c}{ Name } & $\mathbf{1}$ & $\mathbf{2}$ & $\mathbf{3}$ & $\mathbf{4}$ & $\mathbf{5}$ & $\mathbf{6}$ & $\mathbf{7}$ & $\mathbf{8}$ & $\mathbf{9}$ \\
\hline $\mathrm{x}_{1}(\mathrm{Mol} / \mathrm{L})$ & -1 & -1 & -1 & -1 & 0 & +1 & +1 & +1 & +1 \\
$\mathrm{x}_{2}(\mathrm{~h})$ & -1 & -1 & +1 & +1 & 0 & -1 & -1 & +1 & +1 \\
$\mathrm{x}_{3}\left({ }^{\circ} \mathrm{C}\right)$ & -1 & +1 & -1 & +1 & 0 & -1 & +1 & -1 & +1 \\
\hline
\end{tabular}



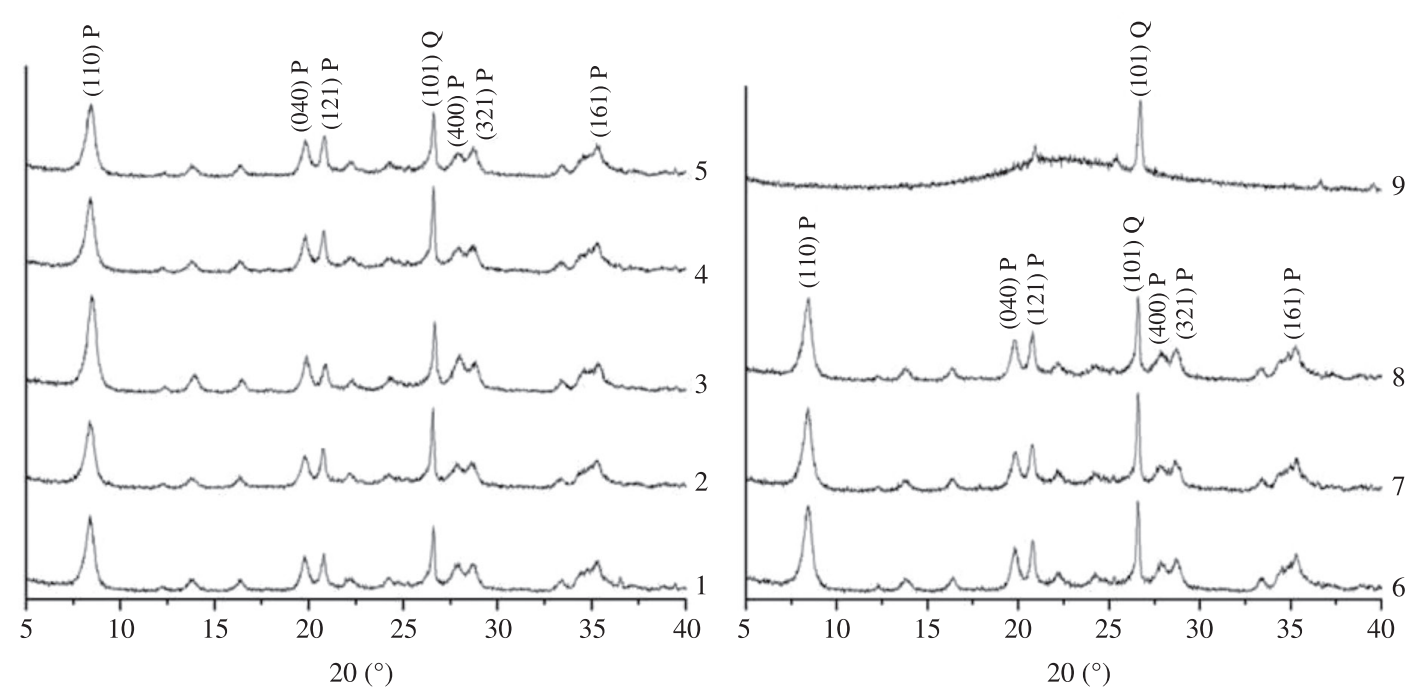

Figure 1. Detail of diffraction patterns of the samples. $\mathrm{P}=$ palygorskite; $\mathrm{Q}=$ quartz. Samples 1 to 5 were activated with $1 \mathrm{M}$ and $3 \mathrm{M} \mathrm{H}_{2} \mathrm{SO}_{4}$ while samples 6-9 were activated with $5 \mathrm{M} \mathrm{H}_{2} \mathrm{SO}_{4}$.

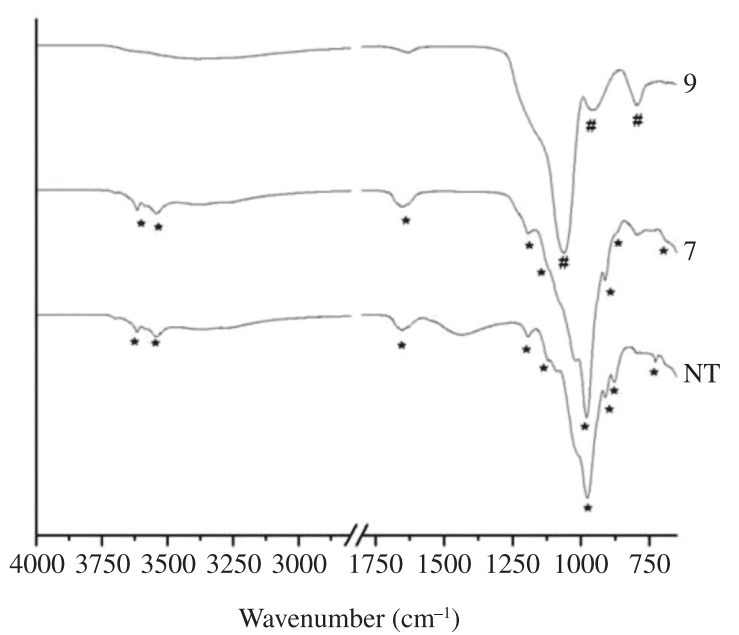

Figure 2. FTIR spectra of the non-treated sample; Sample 7 spectrum representing all activated non-leached samples (the major bands are marked as *) and sample 9, the leached sample (\# marks the presented bands).

bending mode in water (coordinated water and adsorbed water); $1120 \mathrm{~cm}^{-1}$, asymmetric mode of the terminal group $\mathrm{O}^{\prime}-\mathrm{SiO}_{3}$; at $910 \mathrm{~cm}^{-1}, \mathrm{M}-\mathrm{OH}$ bending modes $(\mathrm{M}=\mathrm{Al}, \mathrm{Fe})$ and also symmetric stretching of $\mathrm{O}^{\prime}-\mathrm{SiO}_{3}$; at $800 \mathrm{~cm}^{-1}$, $\mathrm{Fe}_{2}-\mathrm{OH}, \mathrm{M}-\mathrm{OH}(\mathrm{M}=\mathrm{Mg}, \mathrm{Al}, \mathrm{Fe})$ symmetric modes; and at $730 \mathrm{~cm}^{-1}, \mathrm{M}-\mathrm{O}(\mathrm{M}=\mathrm{Al}, \mathrm{Mg})$ vibration. According to the same authors ${ }^{11}$, the band at $983 \mathrm{~cm}^{-1}$ is related to the asymmetric mode of the terminal group $\mathrm{O}^{\prime}-\mathrm{SiO}_{3}$. Another study found that the band at $960 \mathrm{~cm}^{-1}$ could be attributed to $\mathrm{Si}-\mathrm{O}-\mathrm{H}$ vibration, present in activated palygorskite ${ }^{22}$. The present study encountered this band between $970 \mathrm{~cm}^{-1}$ and $978 \mathrm{~cm}^{-1}$. The band at $1198 \mathrm{~cm}^{-1}$, considered by Mendelovici as characteristic of palygorskite ${ }^{18}$, was encountered in most of the studied samples between $1190 \mathrm{~cm}^{-1}$ and $1195 \mathrm{~cm}^{-1}$.
For sample 9, in which the clay was submitted to the most severe treatment conditions, only three bands, marked with (\#), were found: at $1061 \mathrm{~cm}^{-1}$, at $952 \mathrm{~cm}^{-1}$ and at $793 \mathrm{~cm}^{-1}$. According to different authors, when the clay is leached, its characteristic bands disappear and the bands of free silica (at $1090 \mathrm{~cm}^{-1}$, Si-O vibration; at $960 \mathrm{~cm}^{-1}$, $\mathrm{Si}-\mathrm{OH}$ vibration; and at $800 \mathrm{~cm}^{-1}$, $\mathrm{SiOH}$ vibration) are encountered ${ }^{18,19}$.

Table 3 shows the BET surface area and pore volume results for samples of the factorial design. All conditions exhibited higher surface area and pore volume than the NT sample. Besides the activation, other features such as dolomite removal and leaching (sample 9) could also contribute to this increase in the surface area. The BET results also provided the samples' adsorption isotherms (data not shown).

Analyzing the nitrogen adsorption at relative pressure $\mathrm{P} / \mathrm{P}_{0}=0.1$, the lower adsorptions occurred for the samples treated at environmental temperature, with the adsorption rising with the solution concentration. The higher adsorptions were observed for samples activated at $70^{\circ} \mathrm{C}$. In this group, the same trend was noted: higher adsorption for samples treated with more concentrated solutions.

According to Zhang et al. ${ }^{21}$, who studied palygorskite activation using $\mathrm{H}_{2} \mathrm{SO}_{4}$, more concentrated solutions increased the $\mathrm{N}$ adsorption, since more $\mathrm{H}^{+}$could react with the clay, generating microporosity. However, for the palygorskite they used, there was an optimum solution concentration from which the presence of $\mathrm{SO}_{4}{ }^{2-}$ started to restrict the $\mathrm{H}^{+}$mobility, diminishing $\mathrm{N}$ adsorption and generating meso- and macroporosity. This optimun solution concentration was not observed.

The pore size distribution could be considered bimodal: there was a peak around $3.5 \mathrm{~nm}$ and another peak around $60 \mathrm{~nm}$. The intensity of these peaks increased following the same trend as the $\mathrm{N}$ adsorption. Zhang's group ${ }^{21}$ proposed that peaks around $4 \mathrm{~nm}$ were attributable to mesopores (internal surface area) and peaks located at pore sizes 
Table 3. Surface area of the samples after sedimentation (NT sample) and after designed acid treatment with sulfuric acid solution.

\begin{tabular}{lccccccccccc}
\hline \multicolumn{1}{c}{ Sample } & NT & $\mathbf{1}$ & $\mathbf{2}$ & $\mathbf{3}$ & $\mathbf{4}$ & $\mathbf{5}$ & $\mathbf{6}$ & $\mathbf{7}$ & $\mathbf{8}$ & $\mathbf{9}$ \\
\hline Area $\left(\mathrm{m}^{2} / \mathrm{g}\right)$ & 84 & 123 & 169 & 115 & 180 & 150 & 162 & 282 & 167 & 278 \\
Pore Vol. $\left(\mathrm{cm}^{3} / \mathrm{g}\right)$ & 0.24 & 0.36 & 0.38 & 0.36 & 0.43 & 0.39 & 0.40 & 0.62 & 0.41 & 0.70 \\
\hline
\end{tabular}

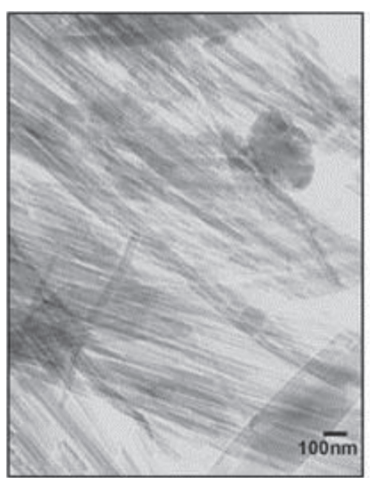

(a)

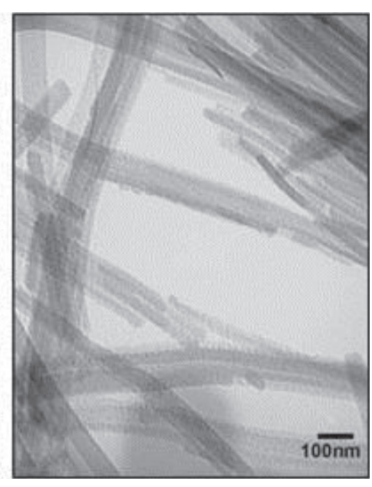

(b)
Figure 3. Transmission electron micrography of (a) non-treated clay and (b) sample 7, and their fibrous aspect before and after acid activation.

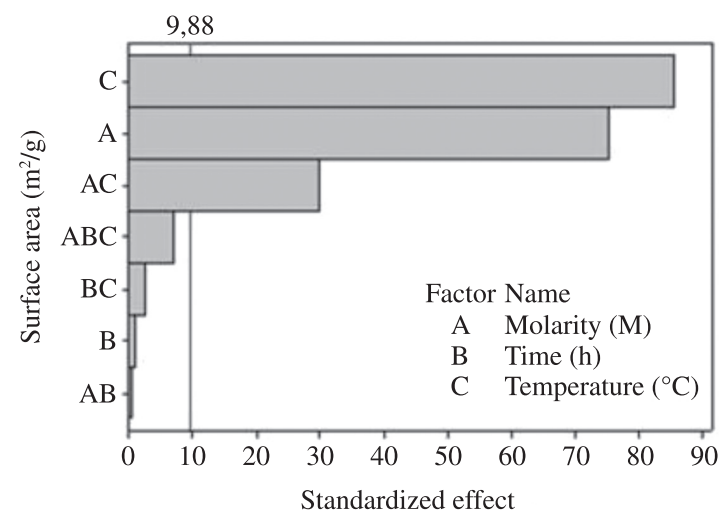

Figure 4. Pareto chart of the effects corresponding to the sulfuric acid factorial design.

larger than $20 \mathrm{~nm}$, were related to non-structural pores (pores formed between clay particles, external surface area). higher the second peak, greater the chance of leaching.

The pore volume and the BET surface area increased according to the same trend observed for $\mathrm{N}$ adsorption. The area increase could be related to channel cleansing, but more likely, to elimination of aggregated impurities. As the treatments proceeded, the $\mathrm{H}_{2} \mathrm{SO}_{4}$ could not only remove the impurities inside the channels, but also cause some leaching (octahedral cations removal).

Considering the initial goal to obtain a high surface area while maintaining the clay structure, the best treatment would be number 7, which consisted of submitting clay to acid activation with $5 \mathrm{M} \mathrm{H}_{2} \mathrm{SO}_{4}$ solution, at $70^{\circ} \mathrm{C}$, for 1 hour. In fact, observing TEM images of the NT sample and of sample 7, Figure 3a, b respectively, both present the fibrous aspect characteristic of this group of clays. A buckle of long fibers and some round particles, probably impurities, can be identified in Figure $3 \mathrm{a}$.

The analytical expression that quantitatively correlates processing parameters (solution molarity, time and temperature) with Y (BET area) is described in Equation 2:

$$
\begin{aligned}
& Y=180.67+37.75 x_{1}+0.50 x_{2}+42.75 x_{3}- \\
& 0.25 x_{1} x_{2}+15.00 x_{1} x_{3}+1.25 x_{2} x_{3}-3.50 x_{1} x_{2} x_{3}
\end{aligned}
$$

The coefficients for solution molarity $\left(\mathrm{x}_{1}\right)$, time $\left(\mathrm{x}_{2}\right)$ and temperature $\left(\mathrm{x}_{3}\right)$ are $37.75,0.50$ and 24.75 , respectively. The time coefficient is considerably lower than the others, meaning that increasing the time from 1 to 5 hours, probably, was not relevant. Solution molarity, temperature and the combination of both parameters were the major parameters affecting surface area. The increase in solution molarity, from low to high level, resulted in an increase of $75.50 \%$ in surface area, whereas the increase in temperature resulted in $85.50 \%$ of area added. Almost all the effects were positive, indicating that they led to an increase in surface area, except the effect resulting from the interaction between molarity and time $(-0.50 \%)$ and also the effect related to the interaction of the three main factors $(-7.00 \%)$.

Figure 4 shows a Pareto chart where the vertical line indicates the minimum statistically significant effect for the level of confidence used.

The Pareto plot shows that, with the exception of time, the other main factors were significant: temperature (C) was the most significant parameter, followed by the solution's molarity (A). The effect of the interaction between temperature and solution molarity (AC) was also significant, since the rise in the temperature of the concentrated solutions led to greater surface areas. These three effects seemed to be the ones that determine improvement to the area in all treatments.

\section{Conclusion}

All conditions used to treat the clay resulted in increased surface area of the clay, but of all the treatments tested in the present work, the one that used $5 \mathrm{M} \mathrm{H}_{2} \mathrm{SO}_{4}$ solution, for 1 hour at $70{ }^{\circ} \mathrm{C}$ is considered the most effective. It resulted in the highest surface area while maintaining the original clay structure and morphology. The experimental design model showed that the temperature of the $\mathrm{H}_{2} \mathrm{SO}_{4}$ solution, its molarity and the interaction of these two parameters were the significant factors in activating the clay.

\section{Acknowledgment}

The authors would like to acknowledge Capes, CNPq and Faperj for their financial support. 


\section{References}

1. Aguiar MRMP, Novaes AC and Guarino AWS. Remoção de Metais Pesados de Efluentes Industriais por Aluminossilicatos. Química Nova. 2002; 25:1145-1154. http://dx.doi.org/10.1590/ S0100-40422002000700015

2. Coelho ACV, Santos PS and Santos HS. Argilas especiais: o que são, caracterização e propriedades. Química Nova. 2007; 30:146-152. http://dx.doi.org/10.1590/S010040422007000100026

3. Frank-Kamenetsk VA. A Crystallochemical Classification of Simple and Interstratified Clay Minerals. Clay Minerals. 1960; 4:161-172. http://dx.doi.org/10.1180/ claymin.1960.004.24.01

4. Luz AB and Almeida SLM. Atapulgita e Sepiolita. Rio de Janeiro: CETEM-MCT; 2005. chap. 9.

5. Lopez-Galindo A, Viseras C and Cerezo P. Compositional, technical and safety specifications of clays to be used as pharmaceutical and cosmetic products. Applied Clay Science. 2007; 36:51-63. http://dx.doi.org/10.1016/j. clay.2006.06.016

6. Carneiro FA, Bezerra ATW and Mesquita IR. Atapulgita de Guadalupe-PI. Um depósito que desperta interesse. In: Anais do Congresso Brasileiro de Geologia; 1984; Rio de Janeiro. Rio de Janeiro: SBG; 1984. v. 33, p. 225.

7. Luz AB, Almeida SLM and Ramos LTS. Estudos Tecnológicos para Aproveitamento da Atapulgita de Guadalupe - PI. Rio de Janeiro: CETEM, 1988. Série Tecnologia Mineral, Seção Beneficiamento.

8. Oliveira CH. Caracterização Tecnológica de Atapulgitas do Piauí. In: Anais do XX Encontro Nacional de Tratamento de Minérios e Metalurgia Extrativa; 2004; Florianópolis. Florianópolis: CETEM; 2004. p. 49-56.

9. Baltar CAM, Luz AB, Oliveira $\mathrm{CH}$ and Baltar LM. Caracterização Mineralógica e Tecnológica de Atapulgitas do Piauí. Rio de Janeiro: CETEM; 2004. chap. 5.

10. Galan E. Properties and applications of Palygorskite-Sepiolite Clays. Clay Minerals. 1996; 31:443-453. http://dx.doi. org/10.1180/claymin.1996.031.4.01

11. Augsburger MS, Strasser E, Perino E, Mercader RC and Pedregosa JC. FTIR and Mössbauer investigation of a substituted palygorskite: Silicate with a channel structure. Journal of Physics and Chemistry of Solids. 1998; 59:175-180. http://dx.doi.org/10.1016/S0022-3697(97)00166-2
12. Frost RL, Locos OB, Ruan H and Kloprogge JT. Near-infrared and mid-infrared spectroscopic study of sepiolites and palygorskites. Vibrational Spectroscopy. 2001; 27:1-13. http:// dx.doi.org/10.1016/S0924-2031(01)00110-2

13. Santos PS and Santos HS. Ocorrências brasileiras de argilas contendo argilominerais do grupo das hormitas (paligorsquita - atapulgita - sepiolita). Cerâmica. 1984; 30:319-335.

14. Pereira Neto J, Almeida SLM and Carvalho RM. Atapulgita do Piauí para a Indústria Farmacêutica. Rio de Janeiro: CETEM; 1993. p. 64.

15. Silva MLG. Obtenção e caracterização de argila piauiense paligorsquita (atapulgita) organofilizada para uso em formulações cosméticas. Teresina: UFPI; 2011.

16. Oliveira RN. Tratamento e caracterização de Atapulgita visando seu uso em máscaras faciais e para reforço em compósitos com PVA. Rio de Janeiro: COPPE; 2010.

17. International Agency for Research on Cancer - IARC. Monographs on the Evaluation of Carcinogenic Risks to Humans. Silica - Summary of Data Reported and Evaluation. World Health Organization; 1997. p. 68

18. Mendelovici E. Infrared study of attapulgite and $\mathrm{HCl}$ treated attapulgite. Clays and Clay Minerals. 1973;21:115-119. http:// dx.doi.org/10.1346/CCMN.1973.0210207

19. Suárez Barrios M, Flores Gonzáles LV, Vicente Rodríguez MA and Martín Pozas JM. Acid activation of a palygorskite with $\mathrm{HCl}$ : development of physico-chemical, textural and surface properties. Applied Clay Science.1995; 10:247-258. http:// dx.doi.org/10.1016/0169-1317(95)00007-Q

20. Frini-Srasra N and Srasra E. Determination of AcidBase Properties of $\mathrm{HCl}$ Acid Activated Palygorskite by Potenciometric Titration. Surface Engineering and Applied Electrochemistry. 2008; 44:401-409. http://dx.doi.org/10.3103/ S1068375508050116

21. Zhang J, Wang K, Chen $\mathrm{H}$ and Wang A. XRF and nitrogen adsorption studies of acid-activated palygorskite. Clay Minerals. 2010; 45:145-156. http://dx.doi.org/10.1180/ claymin.2010.045.2.145

22. Frost RL and Mendelovici E. Modification of fibrous silicate surfaces with organic derivatives: An infrared spectroscopy study. Journal of Colloid and Interface Science. 2006; 294:47-52. PMid:16085086. http://dx.doi. org/10.1016/j.jcis.2005.07.014 